\title{
Study of the Relationship between Various Weather Variables and Final Seed Yield of Soybean Crop during Different Phenological Stages in the Akola Region of Vidarbha, India
}

\author{
Anil Nath ${ }^{1 *}$, A.P. Karunakar ${ }^{2}$ and Arvind Kumar ${ }^{1}$ \\ ${ }^{1}$ Department of Agronomy, G.B.P.U.A.T. Pantnagar, UK.263145, India \\ ${ }^{2}$ Department of Agronomy, Dr. P.D.K.V. Akola, MH.444104, India \\ *Corresponding author
}

\section{Keywords}

Weather variables, Phenophase, Soybean yield, Correlation, Regression

\section{Article Info}

Accepted:

08 August 2018 Available Online: 10 September 2018

A B S T R A C T

Soybean crop is grown predominantly under rainfed conditions in Vidarbha region where weather parameters play an important role at different phenophase of the crop influencing the growth, development and final yield performance. But amongst them, only few parameters are significantly contributing to the crop growth and yield. So in order to identify such parameters and quantify their contribution, a field investigation was carried out with four sowing times and three varieties with four replications and 12 treatments. The crop data, weather data and physico-chemical properties of the soil were obtained during growing season. Detailed observations on phenology and crop growth and yield measurements were made in individual treatment. Correlation coefficients of soybean yield with different weather parameters prevailed during different phenological stages of the crop were worked out. Weather parameters influencing the soybean yield were identified to develop yield prediction equation through regression technique. The correlation and regression study revealed that rainfall during pod formation to full seed development showed highly significant positive impact on soybean seed yield. Higher day time temperature ( $\mathrm{T} \max$ ) during pod formation to seed development was found to have negative impact on soybean yield. The data across the total crop growing period showed that rainfall, humidity (RH-I), GDD and PTU showed significant positive association with seed yield of soybean. Thus the results of this study revealed that pod formation to full seed development stage is the most sensitive stage and rainfall and higher day time temperature $(\mathrm{T} \max )$ are the most significant weather variables for soybean seed yield under rainfed condition in Vidarbha region.

\section{Introduction}

Soybean (Glycine max. L. Merrill) is an important industrial crop, cultivated for oil and protein. Soybean has a prominent position among the legumes that supplement nearly one-third of the world population and popularly known as "Miracle Bean" because of its versatility (Mahesh et al., 2017). In India, soybean is mostly grown under rainfed conditions specially in Madhya Pradesh and Vidarbha region of Maharashtra where weather variability is the most important limiting factor. Crop weather relationship is 
among the most important aspect in successful crop production under rainfed conditions. Soybean crop in Vidarbha region has emerged as a predominant rainy season crop. Year to year soybean production, however, is widely fluctuating in response to agro-environmental conditions. Seasonal and daily variations in weather are the major determinants of crop growth and yield.

The productivity of soybean crop largely depends on the prevailing weather conditions throughout the life cycle. Further, the different weather parameters affect growth and development of crop differently. Soybean is a dicotyledonous photoperiod sensitive crop (short day) and faces thermo-sensitivity in nature. Unstable environment affects important parameters on crop reproductive and vegetative growth. Climate factors such as temperature, photoperiod and moisture stress, exerts a detrimental effect on plant growth and metabolism (Khan et al., 2007). Patel and Franklin (2009) reported that temperature is a critical factor that controls plant growth and development. Sowing dates in turn influence soybean growth stages, due to variation in photoperiod (Han et al., 2006; Kumudini et al., 2007), air temperature (Chen and Wiatrak, 2010), and rainfall distribution and amount during the crop cycle (Hu and Wiatrak, 2012).

Gulluoglu et al., (2006) reported that soybean cannot synthesize some of the necessary hormones in a sufficient level to control its growth and development under high temperature and low humidity, consequently, the plant cannot show its real yield potential. Meotti et al., (2012) observed that $77 \%$ of soybean yield variability was associated with the climate conditions induced by the sowing dates. Therefore, it was contemplated to have an insight on the effect of different weather parameters on the production of soybean crop and to identify the critical phenophases at which soybean crop was most sensitive to the effect of particular weather parameters. Based on the aforementioned facts, this study aims to explore the effect of different weather parameters on the growth and yield of soybean during different phonological stages and identify the most critical phenophase sensitive to a weather parameter.

\section{Materials and Methods}

For data collection, a field investigation was carried out during kharif season of 2014 at the All India Coordinated Research Project on Agro meteorology under Dry land Agriculture Research Centre, Dr. Panjabrao Deshmukh Krishi Vidyapeeth, Akola which is situated in the sub-tropical zone at the latitude of $22^{\circ} 42^{\prime}$ North and longitude of $77^{\circ} 02^{\prime}$ 'East. The altitude of the place is 307.41 meter above mean sea level. Four sowing times $(27 \mathrm{MW}$ July 07, 28 MW-July 14, 29 MW- July 21 and 30 MW-28 July) to create different set of environmental conditions for weather variability and three varieties (JS-335, JS9305 and TAMS 98-21) were laid out in Factorial Randomized Block Design with four replications and 12 treatments. Plot size was $4.5 \mathrm{~m} \times 5.0 \mathrm{~m}$ (Gross) and $3.6 \times 4.6 \mathrm{~m}$ (Net) with $45 \mathrm{~cm} \times 05 \mathrm{~cm}$ spacing. As required gap filling was done on $6^{\text {th }}$ and thinning on $10^{\text {th }}$ day after sowing so as to maintain intra plant spacing of $5 \mathrm{~cm}$.

Recommended dose of nitrogen and phosphorus was applied @ 30:75 kg N: $\mathrm{P}_{2} \mathrm{O}_{5}$ ha $^{-1}$ through urea $(46 \% \mathrm{~N})$ and single super phosphate $\left(16 \%, \mathrm{P}_{2} \mathrm{O}_{5}\right)$, respectively at the time of sowing. Hoeing and hand weeding were given to keep the crop weed free. Plant protection measures were undertaken as per the necessity to protect the crop from semilooper and Spodoptera litura incidence. Chlorpyriphos 25\%@ $@ 20 \mathrm{ml}$ in 10 litres of water was used. The crop data and weather data were obtained during 2014 growing season. Detailed observations on phenology 
and crop growth (plant stand, plant height, leaf area, dry matter weight at different stages) and yield measurements were made in individual treatment. Phenological observations on occurrence of different phenophase were taken in order to know the number of days required from emergence for initiation of different phenophase and its duration and from it total duration from emergence to physiological maturity. Agro-meteorological indices like rainfall distribution, air temperature and relative humidity regime, heliothermal and photothermal units, growing degree days, thermal use efficiency were studied at different phenophase. Important yield attributing characters were studied after the harvest of the crop. Moisture use studies (actual crop water use and crop water productivity) were also done after harvest. Before starting the field experimentation in 2014, physico-chemical properties of the soil were determined. The soil characterized clayey in texture and moderately alkaline in reaction. The experimental data collected during the course of investigation were statistically analyzed with factorial randomized block design programme on computer by adopting standard statistical techniques of analysis of variance. Correlation and regression study was done in order to explore the relationship between various weather variables and final seed yield of soybean crop. Correlation coefficients between seed yield and weather variables were worked out. Weather parameters influencing the soybean yield were identified to develop yield prediction equation through regression technique.

\section{Results and Discussion}

Correlation coefficients of soybean yield with different weather parameters prevailed during different phenological stages of the crop were worked out. The correlation coefficients are presented in Table 1. During the vegetative stage (VG) the weather variables like rainfall, temperatures (maximum and minimum), GDD, and PTU showed significant positive association with seed yield whereas humidity (RH-I and RH-II) showed significant negative association with seed yield. During flowering stage (FL) the weather variables like rainfall, $\mathrm{RH}_{\mathrm{I}}$ and $\mathrm{RH}_{\mathrm{II}}$ showed negative association while temperature (maximum and minimum), GDD and PTU showed significant positive association with seed yield. During the pod formation (PF) to full seed development (FSD) rainfall, minimum temperature and humidity (RH-I and RH-II) showed significant positive association with seed yield whereas maximum temperature showed significant negative correlation with seed yield.

This corroborates the findings of Onat et al., (2017). Onat et al., (2017) observed that the high temperature (Max T) negatively affected the seed yield of different soybean varieties. Mishra and Cherkauer (2010) also indicated that soybean crop yield is strongly correlated with maximum daily temperature during seed filling stage. The data across the total crop growing period showed that rainfall, humidity (RH-I), GDD and PTU showed significant positive association indicating significant role of respective parameter in seed yield production in soybean.

Similarly, linear regression study was done in order to explore the relationship between various weather variables and final seed yield of soybean crop. Weather parameters influencing the soybean yield were identified to develop yield prediction equation through linear regression technique and the resultant relations for different phenophase and total growing period are presented in Table 2 . However, the developed regression model is based on the results of one year investigation and therefore, further experimentations are needed to arrive at valid linear regression equation. 
Table.1 Pearson's correlation coefficients between seed yield and weather variables prevailed during different phenophases of soybean

\begin{tabular}{|c|c|c|c|c|}
\hline Parameters & VG & FL & PF-FSD & Total growing period \\
\hline Rainfall & $0.794 * *$ & -0.464 & $0.884 * *$ & $0.827 * *$ \\
\hline Max.T. & $0.717 * *$ & $0.798 * *$ & $-0.819 * *$ & 0.122 \\
\hline Min.T. & $0.727 * *$ & $0.669 * *$ & $0.704^{*}$ & 0.228 \\
\hline $\mathrm{RH}_{\mathrm{I}}$ & $-0.629 *$ & -0.460 & $0.802 * *$ & $0.643 *$ \\
\hline $\mathrm{RH}_{\mathrm{II}}$ & $-0.591 *$ & $-0.619 *$ & $0.810 * *$ & 0.573 \\
\hline GDD & $0.914 * *$ & $0.932 * *$ & 0.061 & $0.824 * *$ \\
\hline PTU & $0.933 * *$ & $0.944 * *$ & 0.296 & $0.921 * *$ \\
\hline \multicolumn{5}{|c|}{$\begin{array}{l}\text { VG-Vegetative stage, FL-Flowering, PF-Pod formation, } \\
\text { FSD-Full seed development } \\
*=\text { Significant at } 0.05 \text { level } \quad * *=\text { Significant at } 0.01 \text { level }\end{array}$} \\
\hline
\end{tabular}

Table.2 Weather based yield prediction model for soybean crop

\begin{tabular}{|c|c|c|}
\hline Phenophase & \multicolumn{1}{c|}{ Regression equation } & $\mathbf{R}^{\mathbf{2}}$ \\
\hline VG & $\mathrm{Y}=-2484.898+5.539$ Tmax + 115.390 Tmin + 1.064 Rain & 0.853 \\
\hline FL & $\mathrm{Y}=464.130+77.691$ Tmax -97.111 Tmin + 0.914 Rain & 0.705 \\
\hline PF-FSD & $\mathrm{Y}=9857.191-91.816 \mathrm{Tmax}-280.904$ Tmin + 1.048 Rain & 0.814 \\
\hline TOT & $\mathrm{Y}=-5819.282+183.948$ Tmax +1.926 Tmin + 1.060 Rain & 0.872 \\
\hline $\begin{array}{l}\text { VG- Vegetative phase, FL-Flowering, } \text { PF-Pod formation, } \\
\text { FSD-Full seed development, TOT- Total crop growing period }\end{array}$ & \\
\hline
\end{tabular}

The relationship between various weather variables and final seed yield of soybean crop during different phonological stages was analysed for Vidarbha region of India. The correlation and regression study showed that rainfall during pod formation to full seed development showed highly significant positive impact on soybean seed yield. Higher day time temperature ( $\mathrm{T}$ max) during pod formation to seed development was found to have negative impact on soybean yield. The data across the total crop growing period showed that rainfall, humidity (RH-I), GDD and PTU showed significant positive association with seed yield of soybean. Thus the results of this study revealed that pod formation to full seed development stage is the most sensitive stage and rainfall and higher day time temperature ( $\mathrm{T} \max$ ) are the most significant weather variables for soybean seed yield particularly at pod formation to full seed development stage under rainfed condition in Vidarbha region.

\section{References}

Chen, G. H. and Wiatrak, P. 2010. Soybean development and yield are influenced by planting date and environmental conditions in the southeastern coastal plain, United States. Agronomy Journal. 102:1731-1737.

Gulluoglu, L., Arioglu, H. and Arslan, M. 2006. Effect of some plant growth regulators and nutrient complexes on above-ground biomass and seed yield of some soybean grown under heatstressed environment. Journal of Agronomy. 5(2):126-130.

Han, T. F., Wu, C. X., Tong, Z., Mentreddy, R. S., Tan, K. H. and Gai, J.Y. 2006. Post flowering photoperiod regulates 
vegetative growth and reproductive development of soybean. Environmental and Experimental Botany. 55:120-129.

$\mathrm{Hu}, \mathrm{M}$. and Wiatrak, P. 2012. Effect of planting date on soybean growth, yield, and grain quality: Review. Agronomy Journal. 104:785-790.

Khan, A.Z., Khan, H., Ghoneim, A., Khan, R. and Ebid., A. 2007. Seed quality and vigor of soybean as influenced by planting date, density and cultivar under temperature environment. Int. Journal of Agriculture Research. 2(4): 368-376.

Kumudini, S. V., Pallikonda, P. K. and Steele, C. 2007. Photoperiod and e-genes influence the duration of the reproductive phase in soybean. Crop Science.47: 1510-1517.

Mahesh, N., Sreenivas, G., Leela rani, P., Gupta, A., Sreekanth, P.D. and Surekha, K. 2017. Growth and yield of soybean under varied environments and plant densities in south Telangana agro climatic zone. International Journal of
Current Microbiology and Applied Sciences. 6(8):1839-1844.

Meotti, G. V., Benin, G., Silva, R. R., Beche, E. and Mumaro, L. B. 2012. Épocas de semeadura e desempenho agronômico de cultivares de soja. Pesquisa Agropecuária Brasileira.47: 14-21.

Mishra, V. and Cherkauer, K.A. 2010. Retrospective droughts in the crop growing season: Implications to corn and soybean yield in the Midwestern United States. Agricultural and Forest Meteorology. 150:1030-1045

Onat, B., Bakal, H., Gulluoglu, L. and Arioglu, H. 2017.The effects of high temperature at the growing period on yield and yield components of soybean [Glycine $\max$ (L.) Merr] varieties. Turkish Journal of Field Crops. 22(2):178-186.

Patel, D. and Franklin, K.A. 2009. Temperature-regulation of plant architecture. Plant Signaling and Behavior Journal. 4: 577-579.

\section{How to cite this article:}

Anil Nath, A.P. Karunakar and Arvind Kumar. 2018. Study of the Relationship between Various Weather Variables and Final Seed Yield of Soybean Crop during Different Phenological Stages in the Akola Region of Vidarbha, India. Int.J.Curr.Microbiol.App.Sci. 7(09): 1027-1031. doi: https://doi.org/10.20546/ijcmas.2018.709.122 